\title{
Exploration on Countermeasures of Architectural BIM Technical Talents Training in Construction Engineering Major of Higher Vocational Colleges
}

\author{
Fuyong Huang \\ Liaoningjianzhu Vocational University, Liaoning, Liaoyang, 111000
}

Keywords: construction engineering, BIM Technology, talent training, countermeasure analysis

\begin{abstract}
The emergence of building information model technology, also known as BIM technology has revolutionized the construction industry. Nowadays, countries all over the world are promoting BIM technology. There is no exception in China, but BIM technical talent is still lacking. With the continuous development of China's construction industry, the demand for architectural BIM technical talents in the construction market has gradually increased. Nowadays, the demand for BIM technical talents is not only huge, but also the requirements and standards for talents are gradually increasing. Higher education standards for BIM personnel have been put forward. In order to meet the market demand, higher vocational colleges must reform the existing talent training model and build and improve the talent training system. This paper explores and analyzes the countermeasures for BIM technical personnel training in construction engineering major of higher vocational colleges.
\end{abstract}

\section{Introduction}

As a traditional industry, the construction industry is relatively backward in terms of technology and production mode, and the management method is inefficient. Although the overall scale of the building is not very high, it is not high. The productivity of China's construction units is far from the developed countries, only 1/14 of the UK, only 1/19 compared with the US. Therefore, the demand and space of technological development and innovation in China's construction industry is huge, and the emergence of BIM technology just meets such demand. Building Information Modeling (BIM) is a multi-dimensional model information integration technology developed on the basis of CAD technology. Multidimensional refers to multiple dimensions such as time, engineering cost and safety performance based on 3D building model. The role of BIM is to realize the sharing and complete transmission of information related to construction projects during planning, design, construction, operation and maintenance. All participants, such as construction units and contractors, can participate in the construction of the project from concept design to construction completion. Throughout the process, you get information in the model and manipulate the model in the information. The parties have achieved synergy and fundamentally changed the traditional construction project management and operation model.

\section{The Importance and Prospects of BIM Technology}

Nowadays, countries all over the world are vigorously promoting the application of BIM technology, because BIM technology has the advantages of economy and high efficiency, which can bring strong economic, social and environmental benefits. However, the lack of BIM technical talent has greatly hindered the technological development of the construction market. According to the survey data, the main reason for the difficulty in promoting BIM technology is the lack of sufficient training and application experience. At the e-building roundtable, after discussion at the conference, participants agreed that the lack of experienced technical personnel has caused bottlenecks in domestic BIM applications. Participants affirmed that the widespread use of BIM technology requires large-scale education and training. According to the "China Engineering Construction BIM Application Research Report 2012", the main reason why most companies did not use BIM software in 2012 was considered to be the lack of BIM technical talent. 
As a backup talent for BIM technology and a new force for future development, students are the key to the future application and development of BIM technology. Only the in-depth teaching of BIM technology in the courses of universities and higher vocational colleges can realize the large-scale education and training of BIM technology, and finally realize the cultivation of BIM technical talents and lead China's construction industry into the BIM era. Therefore, it is of great significance to explore the training countermeasures of BIM technical talents in architectural engineering. Through the teaching practice and data statistics, the learning cycle and curve of BIM technology for Chinese students are obtained. According to this data, the teaching mode of BIM technology learning for architectural students is obtained, and the teaching experience of BIM technology at home and abroad is used to establish and improve the building class.

\section{Objectives and Contents of BIM Technical Personnel Training in the Construction Engineering Major of Higher Vocational Colleges}

The basic foundation of building BIM technical talents is to master and apply the basic skills of BIM. Students need to be proficient in BIM modeling software to make a variety of data models and related information generated during the construction engineering and construction process into BIM and related 2D projects for architectural design, construction and operation and maintenance applications. Drawings, 3D geometric models, and other related graphics, models, documents, and more. The integrated application of BIM technology is realized by operating BIM application software. However, these capabilities are only the basic requirements and standards for BIM, and are not enough to meet the requirements of BIM technical talents. The significance of BIM is to realize the information sharing and non-destructive transmission of the entire construction process of the construction project, that is, the whole life cycle. This ability of information interaction puts high demands on the engineering ability, BIM skill mastery and collaborative management ability of BIM talents. If students only use software modeling and do not have the ability to solve problems through operating software, then it is not a master of BIM technology. BIM talents must not only be modeled, but also have the ability to lead the team to solve problems. If you don't have both of these capabilities, you can't call them BIM technical talents. BIM technical talents should be technical compound talents and play an important role in construction projects to reflect the value of BIM technology.

\section{Difficulties in Cultivating BIM Technical Talents in the Construction Engineering Major of Higher Vocational Colleges}

Judging from the current application status of BIM technology in China, China's BIM technical talents are relatively scarce, and the demand for BIM technical talents in China's construction industry is very high. In response to the phenomenon of talent shortage, many higher vocational colleges in China have strengthened research and exploration on BIM teaching in recent years. Some colleges have even set up special BIM skill level examinations to hold various forms of BIM technology application competitions. And encourage students to learn BIM, providing a broader platform for higher vocational students BIM can improve. There are also some undergraduate colleges that promote the use of BIM technology by students to deepen the cooperation between schools and enterprises, and increase the research on BIM technology. Nevertheless, in general, most of the higher vocational colleges in China are still in the preliminary exploration stage in BIM teaching. Especially in professional teaching, most vocational colleges lack corresponding teaching experience, and higher vocational colleges are teaching. The level of competence and teaching is uneven. The construction of the BIM technology training base is also in the stage of exploration and trial. In order to better adapt to the development of the modern construction industry, meet the needs of China's construction engineering development and the demand for BIM technical talents, higher vocational colleges must be aware of the current higher vocational education. The problems in the BIM teaching of college architecture majors include the following three aspects:

First, the cost of teaching is higher. At present, many vocational colleges have special BIM 
technology training bases, which also improve the development of talents for BIM technology. However, the BIM technology training base should update and modify the BIM training software and hardware required for the training. In addition, technical training personnel with high professional quality are required. However, many teachers have not been exposed to BIM-related software before, and the training of teachers also requires corresponding time and funds to ensure the quality of BIM teaching. The combination of these factors has led to higher cost and more investment in BIM teaching in higher vocational colleges.

Second, BIM teaching lacks systematic teaching materials. At this stage, the professional information about BIM in China's construction industry can be divided into two types: one is practical teaching materials, with software operation as the main content, the main readers are users and software suppliers of BIM software; the second main Explain and explain the connotation of BIM technology and the basic teaching materials of its use. The purchasers of such teaching materials are mainly project management personnel and enterprise management personnel. Obviously, these two types of textbooks are too monotonous in content and cannot meet the needs of BIM technology development. The types of BIM teaching materials are lacking and not systematic enough. BIM-related professional teaching materials and curriculum arrangements need to be further improved and improved in the future.

\section{Countermeasures for BIM Technical Talents Training in the Construction Engineering Major of Higher Vocational Colleges}

From the current development trend and development status of the construction industry, the wide application of BIM technology is indispensable. As the demand for BIM talent in the construction market continues to increase, higher vocational colleges also pay more attention to BIM teaching courses. BIM technology has strong professional characteristics. When carrying out BIM teaching courses, higher vocational colleges should not regard it as the expansion and extension of CAD courses, but should open relevant courses in schools. When conducting BIM courses, higher vocational colleges can learn from other countries' curriculums, establish BIM simulation laboratories, increase the promotion and construction of BIM courses, and improve the quality of BIM teaching.

In order to solve the current funding problem of BIM technical personnel training in higher vocational colleges, it is necessary to start from three aspects of enterprises, schools and government, in order to fundamentally solve the funding problem. First of all, higher vocational colleges should actively carry out school-enterprise cooperation, and invest in enterprises to build a BIM talent training base for enterprises, so that not only enterprises can get more professional BIM talents, but also schools can obtain more sufficient funds for running schools. In the training of BIM talents, this is a win-win situation for enterprises and schools. Secondly, the government should put forward corresponding policy support and financial support to solve the financial difficulties of the current BIM technical personnel training in higher vocational colleges, establish corresponding BIM technology associations, help higher vocational colleges to solve teacher training problems, and provide more training opportunity.

BIM technology is a highly practical course. If students do not get enough training, the learning effect will be greatly reduced. Therefore, in order to achieve better teaching results, higher vocational colleges should strengthen cooperation with schools and enterprises of related enterprises. Enterprises should cooperate with BIM technology to build a good school-enterprise cooperation platform. Establish a BIM employment agency to help students find opportunities for internships and employment in companies related to BIM technology, so that students can get enough opportunities for development and exercise to promote students' mastery of BIM technology.

The establishment of BIM technology as the direction of graduation design puts forward higher requirements for the knowledge of students' BIM technology. Students need to establish research topics related to BIM technology in construction engineering according to their knowledge, conduct in-depth research, conduct innovative research in the design of the thesis, exert innovative spirit, 
collect various aspects of information and conduct practical investigations, and master new types of technical information. It is conducive to the improvement of the skill level of BIM technical talents in the construction engineering major of the whole higher vocational colleges.

The BIM course of architecture engineering has strong practicality, so teachers can't only carry out theoretical teaching in the teaching process. Teachers should introduce construction projects in the BIM classroom, strengthen the connection between BIM teaching theory and practice, deepen the students' understanding of the knowledge they have learned, and let students learn to apply the knowledge in the textbooks to the actual construction projects to solve problems. ,

Higher vocational colleges can organize students to participate in some BIM-related competitions in construction engineering, let students test their own learning through the platform of the competition, and play their own innovative ability and practical ability through competition, which will be affirmation of students' BIM knowledge learning. In addition, students can be encouraged to participate in some competitions with high gold content, to train students with better learning conditions, and further study, such as "BIM National Design Competition", etc., the school should conduct corresponding training and counseling for the participating students. Arrange the teachers to complete the preparations before the competition and effectively improve the students' practical ability, master the application and innovation of BIM technology.

\section{Conclusion}

All in all, at present, there are still many areas for BIM technical personnel training in China's architectural higher vocational colleges, including insufficient funds, single textbooks, and fewer practical opportunities. To solve these problems fundamentally, the government and schools are needed. In cooperation with the three sides of the enterprise, we can effectively improve the quality of BIM technical talents in China. The application of BIM technology has broad prospects, and the demand for BIM technical talents in the existing construction market is also increasing. Higher vocational colleges should pay more attention to improve the training strategy of improving BIM technical talents.

\section{References}

[1] Yin Guoying. Discussion on BIM technical personnel training in higher vocational construction engineering under the new normal[J].Construction Engineering Technology and Design, 2016 (22):3382.

[2] Zhao Xuefeng, Li Yanfeng, Wang Huizhen, et al. Research on BIM technical personnel training mode of architectural engineering specialty [J]. China Electric Power Education, 2015 (02): 53-54.

[3] WANG Xiaoliang, GUO Ronghua. Research on BIM technical personnel training in higher vocational construction engineering under the new normal state[J]. Journal of Hebei Software Vocational and Technical College, 2016(01): 24-26.

[4] Chen Jinhua, Guo Hualun. Thoughts on setting up BIM course in the professional course system of higher vocational construction cost[J].Journal of Taiyuan Urban Vocational and Technical College,2015(02):103-104.

[5] Chai Meijuan. Application Research and Practice of BIM in Talent Cultivation of Higher Vocational College Buildings[J].Journal of Zhejiang Business and Technology College, 2017, 16(01): 68-72. 